JPE (Jurnal Pendidikan Edutama) Vol. 7 No. 2 Juli 2020

P-ISSN: 2339-2258 (Print) E-ISSN: 2548-821X (Online)

http://ejurnal.ikippgribojonegoro.ac.id/index.php/JPE

\title{
PENGEMBANGAN MEDIA EMODUL BERBASIS MULTIPLE INTELLEGENCES UNTUK MENINGKATKAN PEMAHAMAN KONSEP STRUKTUR BUMI
}

\author{
Sinta Aniati ${ }^{1}$, I Nyoman Sudana Degeng ${ }^{2}$, Sugito $^{3}$, Utama Alan Deta ${ }^{4}$ \\ 1,3Program Pascasarjana, Universitas PGRI Adi Buana Surabaya \\ ${ }^{2}$ Program Pascasarjana, Universitas Negeri Malang \\ ${ }^{4}$ Fakultas Matematika dan IPA, Universitas Negeri Surabaya \\ email: shint.first@gmail.com \\ email: nyoman.sudana.d.fip@um.ac.id \\ email: sugitounipa@gmail.com \\ email: utamadeta@unesa.ac.id
}

\begin{abstract}
In science learning students should build their own knowledge by discovering concepts through observing and investigating natural phenomena. The limitations media make it difficult for teachers to teach material learning. In the earth material structure students need direct observation because the nature of the material tends to be abstract. Students need to concretize the abstract concept into a concrete concept. Therefore, the purpose of this research to determine attractiveness of emodule media science learning based on multiple intelligences of earth structure material and differences in understanding of concept between control and experimental class that use emodule. This research and development uses $R \& D$ with Borg and Gall adapted development model. The subjects of this research were 120 seventh grade students at SMP Negeri 1 Sugio. Instruments used was a validation sheet, a questionnaire of elegability and product attractiveness for students, as well as a test sheet. The media development result have valid and suitable for use with average validity $88.30 \%$ from material expert, design, and science teacher. The research results obtained media attractiveness value $77.8 \%$. The $Z$ test obtained significance 0.00 so that it can be concluded that learning media is interesting for students. From $t$ test on posttest value, obtained significance 0.00. This means that there are differences in the results of understanding concept of earth structure material between student at control and experimental class.
\end{abstract}

Keywords: media, emodule, multiple intelligences, the earth structure

Abstrak: Dalam pembelajaran IPA siswa hendaknya membangun pengetahuan mereka sendiri dengan menemukan konsep melalui pengamatan dan penyelidikan fenomena alam. Keterbatasan media menjadikan guru kesulitan dalam menyampaikan materi pembelajaran. Pada materi struktur bumi siswa memerlukan pengamatan langsung karena sifat materi tersebut cenderung abstrak. Siswa perlu mengkonkritkan konsep yang abstrak tersebut menjadi konsep konkret. Oleh karena itu, tujuan dari penelitian ini untuk mengetahui kemenarikan media pembelajaran IPA emodul berbasis multiple intellegences materi struktur bumi dan perbedaan pemahaman konsep antara kelas kontrol dan eksperimen yang menggunakan emodul. Penelitian dan pengembangan ini memakai model penelitian $R \& D$ dengan model pengembangan Borg and Gall yang telah diadaptasi. Subjek dari penelitian ini adalah 120 siswa kelas tujuh yang ada di SMP Negeri 1 Sugio. Instrumen yang digunakan berupa lembar validasi, angket kelayakan dan kemenarikan produk bagi siswa, serta lembar tes. Hasil pengembangan media memenuhi kriteria valid dan layak digunakan dengan rata-rata tingkat kevalidan 88,30\% dari ahli materi, desain, dan guru IPA. Hasil penelitian memperoleh nilai kemenarikan media sebesar 77,8\% .Uji Z mendapatkan nilai signifikansi 0,00 sehingga dapat disimpulkan media pembelajaran menarik bagi siswa. Dari uji $t$ terhadap nilai postes 
didapatkan signifikansi 0,00. Hal ini berarti bahwa terdapat perbedaan pemahaman konsep materi struktur bumi antara siswa kelas kontrol dan eksperimen.

Kata Kunci: media, emodul, multiple intellegences, struktur bumi

\section{PENDAHULUAN}

Pembelajaran IPA sedapat mungkin dilakukan sesuai dengan karakteristik IPA. IPA merupakan proses dinamis mencari pengetahuan melalui mencari, menyelidiki, dan memverivikasi perilaku alam yang terjadi di lingkungan sekitar (Nowrgu \& Otum, 2014). Siswa hendaknya membangun pengetahuan mereka sendiri dengan menemukan konsep melalui kegiatan pengamatan dan penyelidikan fenomena alam di lingkungan sekitar mereka. Dalam pembelajaran IPA siswa dilatih berfikir kritis untuk mencari jawaban atas masalah yang mereka hadapi dengan menemukan hubungan antar fakta yang ada.

Pada materi struktur bumi, gempa bumi, dan gunung api siswa memerlukan pengamatan langsung karena sifat materi tersebut cenderung abstrak (Mahmudah et $a l, 2018)$. Untuk membangun pengetahuan mereka sendiri dalam mempelajari struktur bumi, siswa perlu mengkonkritkan konsep yang abstark tersebut menjadi konsep konkret. Pemahaman konsep mengenai struktur bumi akan menjadi lebih baik apabila siswa diajak mengamati fenomena langsung yang terjadi pada struktur bumi.

Berdasarkan wawancara yang dilakukan pada guru IPA kelas VII SMP Negeri 1 Sugio, hasil belajar siswa materi struktur bumi banyak yang belum memenuhi standar KKM (Kriteria Ketuntasan Minimal). Guru juga menunjukkan bahwa media pembelajaran yang digunakan dalam materi struktur bumi hanya terbatas dalam bentuk bahan ajar cetak. Hasil pengamatan peneliti terhadap bahan ajar yang digunakan di sekolah tersebut ditemukan beberapa masalah sebagai berikut: (1) bahasa pada buku ajar sebagian besar berorientasi pada penulis bukan pada siswa, (2) penjelasan pada buku ajar belum bisa memvisualisasikan lapisan bumi dan fenomena di dalamnya secara jelas, (3) belum adanya pembelajaran kompetensi ketrampilan yang dilatihkan, dan (4) belum adanya pembahasan dari kegiatan dalam buku ajar sehingga siswa kesulitan mengaitkan kegiatan yang mereka lakukan dengan konsep yang dipelajari.

Keterbatasan bahan ajar menjadikan guru mengalami kesulitan dalam membelajarkan konsep struktur bumi. Konsep tentang bumi dan fenomena yang ada di dalamnya seperti lapisan penyusun bumi, pergerakan lempeng, gempa bumi, gunung berapi, dan siklus hidrologi yang dalam buku ajar hanya sebatas gambar, membuat siswa kesulitan memahami proses yang sebenarnya terjadi. Hal ini akhirnya berdampak pada tidak tercapainya hasil belajar yang sesuai dengan standar KKM.

Pemahaman konsep dalam konteks IPA adalah kemampuan siswa dalam menghubungkan konsep satu sama lain sehingga bisa diterapkan untuk memecahkan masalah (Holme et al, 2015). Pemahaman konsep IPA harus dikuasai oleh siswa, hal ini dikarenakan konsep IPA saling berkaitan satu sama lain. Rendahnya pemahaman konsep sebelumnya menyebabkan siswa mengalami kesulitan memahami konsep lain yang saling berhubungan.

Media pembelajaran dapat memberikan kesamaan pengalaman kepada siswa tentang peristiwa-peristiwa di lingkungan mereka, serta memungkinkan terjadinya interaksi langsung dengan guru, masyarakat, dan lingkungan sekitarnya (Suherman, 2009). Media pembelajaran yang sesuai dapat memberikan pengalaman tentang peristiwa yang tidak mungkin dialami secara langsung. Selain itu media pembelajaran juga memberikan fenomena nyata dari konsep yang bersifat abstrak. Hal ini diperkuat oleh Hasanudin (2017) bahwa media dapat digunakan untuk menyalurkan pesan dari pengirim ke penerima sehingga 
dapat merangsang pikiran, perasaan, perhatian, dan minat siswa sedemikan rupa, sehingga proses belajar terjadi (Hasanudin, 2017).

Emodul berupa modul yang berbasis teknologi komputer dan berisi penggalanpenggalan dengan pertanyaan di setiap penggalan agar membuat pengguna lebih mudah memahami materi. Restrukturisasi materi dalam media emodul dibuat dengan penambahan ilustrasi gambar, animasi, dan video (Meilinda et al, 2009). Emodul merupakan variasi dari modul cetak yang biasa digunakan. Teknologi informasi dimanfaatkan dalam emodul sehingga sajian yang diberikan lebih interaktif dan menarik. Dalam emodul kita bisa menambahkan multimedia (gambar, animasi, audio, dan video) dan evaluasi interaktif sehingga interaksi antara sumber belajar dan siswa dapat leih terbangun.

Emodul adalah sarana belajar yang efektif dan efisien. Hal ini disebabkan karena emodul bisa digunakan dimana saja dan kapan saja. Karena merupakan penggabungan dari media cetak dan computer, maka emodul dapat menyajikan informasi secara terstruktur, menarik, serta memiliki tingkat interaktifitas yang tinggi. Selain itu, proses pembelajaran tidak lagi bergantung pada instruktur sebagai satusatunya sumber informasi (Gunadharma, dalam Sugianto et al, 2013). E-modul sangat memberikan kontribusi pada pembelajaran era digital dan mudah bersahabat dengan kaum milenial (Hasanudin, 2020).

Pengembangan emodul pada mata pelajaran IPA sejauh ini terus mengalami perkembangan dan belum menemukan masalah yang berarti. Penelitian pengembangan emodul pada pokok bahasan interaksi makhluk hidup dengan lingkungannya, berdasarkan uji validitas ahli dan tanggapan dari siswa, emodul yang dikembangkan valid dan efektif untuk digunakan serta mampu meningkatkan hasil belajar siswa (Samiasih et al, 2017).

Pada dasarnya manusia mempunyai tujuh jenis kecerdasan, yaitu kecerdasan bahasa, matematis logis, spasial, kinestetis, jasmani, musical, interpersonal, dan kecerdasan intrapersonal (Gadner, 1983).
Semenjak munculnya teori ini, teori multiple intelligence dirasa teori kecerdasan paling mutakhir yang mampu mengusung konsep pembagian kecerdasan pada diri manusia (Hasanudin \& Fitrianingsih, 2020).

Penjabaran ketujuh kecerdasan menurut Gadner adalah sebagai berikut: (1) kecerdasan bahasa merupakan kecakapan berpikir dengan kata-kata dan bahasa, (2) kecerdasan matematis logis merupakan kecakapan memecahkan perhitungan matematis, (3) kecerdasan spasial merupakan kecakapan memvisualisasikan gambar, (4) kecerdasan spasial kinestetis tubuh merupakan kecakapan dalam gerakan dan ketrampilan kecekatan kinestetik tubuh, (5) kecerdasan musikal merupakan kecakapan menghargai musik, melodi, dan nada, (6) kecerdasan interpersonal merupakan kecakapan berinteraksi dengan orang lain, dan (7) (kecerdasan intrapersonal merupakan kecakapan memahami diri sendiri dan orang lain.

Inti dari pembelajaran berbasis majemuk adalah bagaimana seorang pendidik mengemas gaya mengajar agar mudah dipahami peserta didik, yaitu dengan pengenalan kecerdasan yang mereka miliki (Munif Chatib, 2012). Peserta didik dalam hal ini siswa, tidak hanya belajar dengan menggunakan salah satu kecerdasan yang mereka miliki, tetapi juga dengan mengkombinasikan beberapa kecerdasan lain yang ada pada diri mereka. Hal ini dimaksudkan untuk mengoptimalkan beberapa kecakapan yang mereka miliki untuk meningkatkan hasil pembelajaran.

Berdasarkan latar belakang permasalahan di atas, perlu adanya solusi untuk membelajarakan IPA khususnya materi struktur bumi. Dalam penelitian ini, peneliti mencoba mengembangkan media pembelajaran emodul berbasis multiple intellegences materi struktur bumi. Emodul menggunakan aplikasi android studio, aplikasi photoshop untuk pembuatan info grafis, dan aplikasi after effect untuk pembuatan animasi. Emodul ini dapat digunakan tanpa harus terkoneksi internet dan dilengkapi info grafis, video, animasi yang mendukung materi pembelajaran, serta latihan soal. Penelitian ini memiliki 
tujuan untuk mengetahui kemenarikan media pembelajaran IPA emodul berbasis multiple intellegences materi struktur bumi di SMP dan mengetahui perbedaan pemahaman konsep siswa yang ada di kelas kontrol dan eksperimen dalam menggunakan emodul tersebut.

\section{METODE PENELITIAN}

Model penelitian yang digunakan dalam penelitian ini adalah model penelitian R\&D (Research and Development) yang berorientasi pada produk dalam bidang pendidikan (Sugiyono, 2012). Sedangkan model pengembangan dalam penelitian ini menggunakan pada model pengembangan Borg dan Gall yang efektif dalam mengembangkan media yang peneliti lakukan.

Penelitian dilakukan pada 120 siswa kelas VII di SMP Negeri 1 Sugio tahun ajaran 2019/2020. Teknik sampling yang digunakan adalah simple random sampling karena anggota populasi dianggap homogen yaitu sama-sama berada pada kelas VII. Instrumen yang digunakan adalah lembar validasi materi, desain, dan guru mata pelajaran; angket kelayakan bagi siswa, angket kemenarikan bagi siswa, dan lembar tes. Teknik analisis data yang digunakan adalah teknik analisis pada media pembelajaran dan nilai tes.

Prosedur pengembangan Borg dan Gall diadaptasi menjadi empat tahap, yaitu tahap prapengembangan, tahap pengembangan produk, tahap validasi dan revisi, dan tahap uji coba lapangan. a. Tahap Prapengembangan

Pada tahap ini dilakukan analisis terhadap kompetensi dan konsep-konsep yang akan dibelajarkan ke dalam media emodul yang dikembangkan. Tahap ini meliputi kegiatan mengakaji kurikulum yang ada, pengamatan lapangan, penyeleksian materi dan bahan, serta penyusunan draf media emodul.

\section{b. Tahap Pengembangan Produk}

Pada tahap ini dilakukan pengelolaan isi dan struktur, penyusunan kegiatan dalam pembelajaran, kegiatan praktikum, dan instrumen penilaian.

\section{c. Tahap Validasi dan Revisi}

Kegiatan pada tahap ini bertujuan mengetahui kelayakan draf awal hasil dari tahap pengembangan. Hasil akhir dari tahap ini adalah draf media emodul yang lebih sempurna. Validasi produk dilaksanakan melalui telaah dari kelompok ahli, yaitu ahli materi, ahli desain, dan praktisi/guru mata pelajaran. Kegiatan validasi produk dilakukan oleh ahli materi, desain, dan guru IPA. Kualifikasi ketiga ahli sebagai validator adalah sebagai berikut: (1) dosen universitas atau guru dengan pendidikan formal minimal gelar master dalam program studi fisika atau teknologi pendidikan, (2) menguasai multimedia, dan (3) menguasai materi ilmu bumi. Hasil evaluasi dari kelompok ahli selanjutnya digunakan sebagai bahan acuan dalam perbaikan media emodul.

Rata-rata hasil penilaian validator ditentukan oleh presentase dan kategori menurut Tabel 1:

Tabel 1. Kategori Validitas dan Kelayakan Emodul (Sugiyono, 2012)

\begin{tabular}{ccc}
\hline $\begin{array}{c}\text { Presentase } \\
(\%)\end{array}$ & Tingkat Validasi & Kriteria Kelayakan \\
\hline $90-100$ & Sangat valid & sangat layak, tidak perlu revisi \\
$75-89$ & valid & layak, tidak perlu revisi \\
$65-74$ & Cukup valid & Cukup layak, perlu revisi \\
$55-64$ & Kurang valid & Kurang layak, perlu revisi \\
$0-54$ & Sangat tidak valid & tidak layak, revisi total \\
\hline
\end{tabular}

Emodul IPA berbasis multiple intellegences yang dikembangakan sudah dapat dipergunakan sebagai media pembelajaran dalam proses belajar siswa apabila memperoleh skor validasi minimal 70 . 


\section{d. Tahap Uji Coba Lapangan}

Tahap uji coba lapangan melibatkan 15 siswa kelas VII. Siswa yang dilibatkan dalam uji coba lapangan terdiri dari masing-masing lima siswa dengan prestasi belajar rendah, sedang, dan tinggi. Tahapan ini diperlukan untuk mengetahui apakah draf produk media emodul yang telah dikembangkan pada tahap sebelumnya layak digunakan oleh siswa. Hasil akhir dari tahap ini adalah produk emodul yang telah sempurna dan dapat digunakan oleh siswa.

Angket yang diberikan kepada siswa mengandung penilaian dari aspek rekayasa perangkat lunak, komunikasi visual, dan pembelajaran dalam media. Selanjutnya kategori kelayakan media pembelajaran untuk siswa seperti ditunjukkan pada tabel 2.

Tabel 2. Kriteria Kelayakan Media Pembelajaran untuk Siswa

\begin{tabular}{ccc}
\hline Skor & Kriteria & Rentang Nilai \\
\hline 5 & Sangat layak & $4,2<\mathrm{x}$ \\
4 & layak & $3,4<\mathrm{x} \leq 4,2$ \\
3 & Cukup layak & $2,6<\mathrm{x} \leq 3,4$ \\
2 & Kurang layak & $1,8<\mathrm{x} \leq 2,6$ \\
1 & Sangat kurang layak & $\mathrm{x} \leq 1,8$ \\
\hline
\end{tabular}

Setelah diketahui media pembelajaran yang dikembangkan valid dan layak untuk digunakan oleh siswa, maka dilakukan penelitian untuk mengetahui kemenarikan media emodul dan perbedaan pemahaman konsep antara siswa kelas kontrol dan eksperimen dalam menggunakan media emodul.

Prosedur penelitian yang dilakukan menggunakan one group pretest-posttest design yaitu sebuah sampel kelas diberikan tes awal (pretes) untuk mengetahui pengetahuan awal siswa. Setelah mendapatkan data tersebut, peneliti memberikan perlakuan berupa pembelajaran menggunakan media pembelajaran emodul berbasis multiple intellegences. Kemudian diberikan tes setelah perlakuan (postes). Rancangan penelitian disusun menurut tabel 3:

Tabel 3. Rancangan Penelitian

\begin{tabular}{|c|c|c|c|}
\hline Kelompok & Pretes & Perlakuan & Postes \\
\hline Eksperimen & $\mathrm{O}_{1}$ & $\mathrm{X}$ & $\mathrm{O}_{2}$ \\
\hline Kontrol & $\mathrm{O}_{3}$ & - & $\mathrm{O}_{4}$ \\
\hline
\end{tabular}

Kemenarikan media pembelajaran Emodul berbasis multiple intellegences dapat dilihat dari hasil jawaban angket respon siswa. Rata-rata hasil angket respon siswa ditentukan oleh presentase dan kriteria menurut tabel 4.

Tabel 4. Kriteria Kemenarikan Emodul

\begin{tabular}{cc}
\hline Presentase (\%) & Tingkat Kemenarikan \\
\hline $90-100$ & Sangat menarik \\
$70-89$ & menarik \\
$50-69$ & Cukup menarik \\
$55-64$ & Kurang menarik \\
$0-49$ & Tidak menarik \\
\hline
\end{tabular}

Tabel diadaptasi dari Elice (2016)

Media pembelajaran IPA emodul berbasis multiple intellegences yang dikembangkan dianggap menarik sebagai media pembelajaran dalam kegiatan belajar disekolah jika memiliki skor kemenarikan minimal 70. Kemenarikan media 
pembelajaran selanjutnya dianalisis dengan menggunakan uji $\mathrm{Z}$ dua pihak menggunakan software analisis Statistical Package for Social Sciences (SPSS) 19 for windows.

Perbedaan pemahaman konsep struktur bumi antara siswa kelas kontrol dan eksperimen dapat diketahui dengan uji $\mathrm{t}$ terhadap nilai postes yang diberikan setelah pembelajaran selesai. Sebelum dilakukan uji t, harus dilakukan uji persyaratan analisis untuk memenuhi persyaratan uji statistik parametrik yang meliputi uji normalitas dan homogenitas data. Semua pengujian tersebut dilakukan menggunakan software SPSS 19.

\section{HASIL DAN PEMBAHASAN}

Model penelitian R\&D (Research and Development) dengan model pengembangan Borg and Gall yang telah diadaptasi terlaksana dengan baik. Hasil validasi produk media pembelajaran mendapatkan data kuantitatif seperti pada tabel 5.

Tabel 5. Hasil Validasi Emodul

\begin{tabular}{cccc}
\hline No & Ahli & Presentase & Kategori \\
\hline 1 & Materi & $94,0 \%$ & Sangat valid \\
2 & Desain & $85,0 \%$ & Valid \\
3 & Guru IPA & $86,0 \%$ & Valid \\
\hline Rata-rata & $\mathbf{8 8 , 3 \%}$ & Valid \\
\hline
\end{tabular}

Ahli materi memberikan hasil validasi nilai rata-rata sebesar $94,0 \%$. Dari nilai tersebut dapat ditarik kesimpulan bahwa media emodul layak dan valid sesuai kategori validitas dan kelayakan pada tabel 1. Perbaikan produk perlu dilakukan berdasarkankan data kualitatif hasil validasi materi yakni : (1) perlu penambahan tujuan pembelajaran dengan ranah pengetahuan tingkat tinggi, (2) perlu penambahan tujuan pembelajaran yang mencantumkan kompetensi ketrampilan, dan (3) perlu penambahan gambar dan video nyata pada media dan bukan hanya sekedar animasi. Selanjutnya perbaikan dilakukan berdasarkan saran ahli materi sehingga media valid dan layak sebagai berikut: (1) penambahan tujuan pembelajaran siswa mampu menganalisis proses terjadinya pergerakan lempeng bumi, (2) penambahan tujuan pembelajaran siswa mampu menyajikan tindakan evakuasi bencana alam dalam bentuk poster, dan (3) penambahan gambar bumi yang ditangkap oleh satelit dan video nyata proses terjadinya gunung meletus.

Nilai rata-rata yang diberikan oleh ahli desain sebesar $85,0 \%$. Berdasarkan tabel 1, dapat diketahui bahwa media pembelajaran valid dan layak untuk digunakan. Data kualitatif berupa komentar ahli desain menyarankan beberapa perbaikan mengenai format penulisan emodul disesuaikan dengan format penulisan buku dan pemilihan jenis huruf yang lebih menarik dan mudah dibaca. Media valid dan layak setelah dilakukan perbaikan berdasarkan masukan dari ahli desain, yaitu dengan penulisan format emodul yang disesuaikan dengan format penulisan buku dan penggunaan tipe huruf "Verdana" yang lebih menarik dan mudah terbaca oleh siswa.

Guru mata pelajaran IPA memberikan nilai validasi rata-rata sebesar $86,0 \%$. Nilai validasi tersebut menunjukkan bahwa media emodul valid dan layak. Dari komentar guru diketahui perlu beberapa perbaikan yakni: (1) penataan urutan materi harus disusun lebih urut, (2) soal yang diberikan pada latihan harus disusun urut berdasarkan urutan materi yang dipelajari, dan (3) perlu pengacakan pilihan jawaban pada latihan soal apabila dilakukan pengulangan pengerjaan soal. Revisi dilakukan berdasarkan saran guru sehingga media valid dan layak digunakan dengan rincian sebagai berikut: (1) penataan materi lebih diurutkan, (2) penataan latihan soal lebih diurutkan berdasarkan urutan materi yang dipelajari, dan (3) dilakukan pengacakan pilihan jawaban pada latihan soal apabila dilakukan pengulangan pengerjaan soal. 
Secara menyeluruh diperoleh nilai rata-rata dari ketiga validator sebesar $88,3 \%$, sehingga dapat disimpulkan media emodul valid dan layak dipakai dalam kegiatan pembelajaran.
Dari tahap uji coba lapangan yang dilakukan didapatkan hasil sebagai berikut:

Tabel 6. Hasil Uji Coba Lapangan

\begin{tabular}{cccc}
\hline No & Aspek & Skor Rata-rata & Kriteria \\
\hline 1 & Rekayasa Perangkat Lunak & 3,24 & Layak \\
2 & Komunikasi Visual & 3,37 & Layak \\
3 & Pembelajaran & 3,32 & Layak \\
\hline \multicolumn{2}{c}{ Rata-rata } & $\mathbf{3 , 3 1}$ & Layak \\
\hline
\end{tabular}

Dari tabel 6, dapat diketahui bahwa skor rata-rata dari aspek rekayasa perangkat lunak, komunikasi visual, dan pembelajaran sebesar 3,31. Merujuk pada tabel 2, maka dapat diketahui bahwa media emodul yang dikembangkan termasuk kategori cukup layak. Media pembelajaran emodul dianggap siswa cukup layak untuk mereka manfaatkan dalam proses pembelajaran. Siswa merasa cukup memahami materi dan tertarik belajar menggunakan media pembelajaran IPA emodul berbasis multiple intellegences materi struktur bumi.
Selanjutnya tingkat kemenarikan siswa pada media pembelajaran IPA Emodul berbasis multiple intellegences dapat diketahui dari jawaban angket kemenarikan terhadap media emodul oleh siswa. Angket kemenarikan diberikan kepada 60 siswa kelas VII SMP Negeri 1 Sugio yang sudah diberikan pretes, perlakuan (treatment) dan postes. Respon siswa kelas eksperimen terhadap 16 butir pertanyaan dalam angket media pembelajaran emodul ditunjukkan pada gambar berikut:

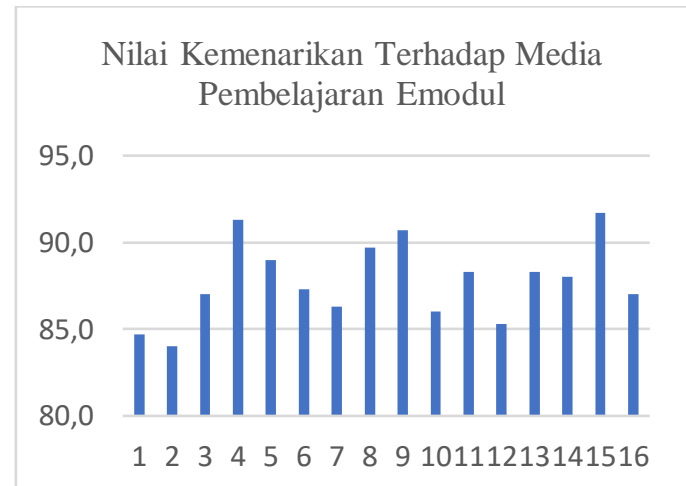

Gambar 1. Hasil Angket Kemenarikan Terhadap Media Pembelajaran

Dari gambar 1 di atas dapat dilihat bahwa nilai tertinggi sebesar $91,7 \%$ pada butir item nomor 15 , dimana siswa merasa sangat mudah memahami materi dan dapat menyelesaikan soal yang ada dalam latihan soal dengan bantuan media pembelajaran IPA Emodul berbasis multiple intellegences pada materi struktur bumi. Nilai minimum ada pada butir item angket nomor 2, yakni sebesar $84,0 \%$ siswa yang merasa tertarik sebelum memulai pembelajaran. Secara keseluruhan nilai rata-rata kemenarikan siswa terhadap media pembelajaran sebesar $77,8 \%$.

Selanjutnya hasil penilaian angket siswa terhadap kemenarikan media pembelajaran dianilisis menggunakan uji $\mathrm{Z}$ menggunakan SPSS. Dari hasil Uji Z, didapatkan nilai signifikansi sebesar 0,00. Karena $0,00<0,05$ maka dapat disimpulkan bahwa media pembelajaran IPA Emodul berbasis multiple intellegences menarik bagi siswa kelas VII di SMP Negeri 1 Sugio. 
Peneliti melakukan uji normalitas

berikut: pada nilai pretes siswa dengan hasil sebagai

Tabel 7. Hasil Uji Normalitas Nilai Pretes

\begin{tabular}{ccc}
\hline Kelas & Sig. Kolmogorov-Smirnov & Sig. Shapiro-Wilk \\
\hline Kontrol & 0,14 & 0,22 \\
Eksperimen & 0,16 & 0,21 \\
\hline
\end{tabular}

Berdasarkan tabel 7 di atas, diketahui pada kolom Kolmogorov-Smirnov nilai signifikansinya 0,14 pada kelas kontrol dan 0,16 pada kelas eksperimen. Pada kolom Shapiro Wilk nilai signifikansinya 0,22 pada kelas kontrol dan 0,21 pada kelas eksperimen. Nilai-nilai tersebut lebih dari 0,05 , sehingga dapat disimpulkan bahwa seluruh data penelitian terdistribusi normal.

Uji homogenitas yang dilakukan terhadap nilai pretes mendapatkan nilai signifikansi sebesar 0,961. Karena nilai $0,961>0,05$ maka dapat disimpulkan bahwa nilai pretes kelas kontrol dan kelas eksperimen adalah sama atau homogen.

Pemahaman konsep materi struktur bumi dengan menggunakan media pembelajaran IPA emodul berbasis multiple intellegences pada materi struktur bumi diukur dari hasil nilai postes setelah pembelajaran selesai dilakukan. Nilai postes pada kelas kontrol dan eksperimen dapat dilihat pada tabel di bawah ini:

Tabel 8. Hasil Nilai Postes

\begin{tabular}{ccccc}
\hline \multirow{2}{*}{ Kelas } & \multicolumn{3}{c}{ Nilai } & Siswa tuntas KKM \\
\cline { 2 - 5 } & Minimal & Maksimal & Rata-rata & \\
\hline Kontrol & 60,0 & 96,0 & 80,7 & 22 \\
Eksperimen & 72,0 & 100,0 & 86,9 & 30 \\
\hline
\end{tabular}

Dari tabel 8 di atas dapat diketahui seluruh siswa pada kelas eksperimen memiliki nilai yang memenuhi standar KKM, sedangkan pada kelas kontrol hanya 22 orang siswa yang mendapatkan nilai postes yang memenuhi standar. Pemahaman konsep pada siswa kelas kontrol dan eksperimen seperti digambarkan pada gambar 2 di bawah ini:

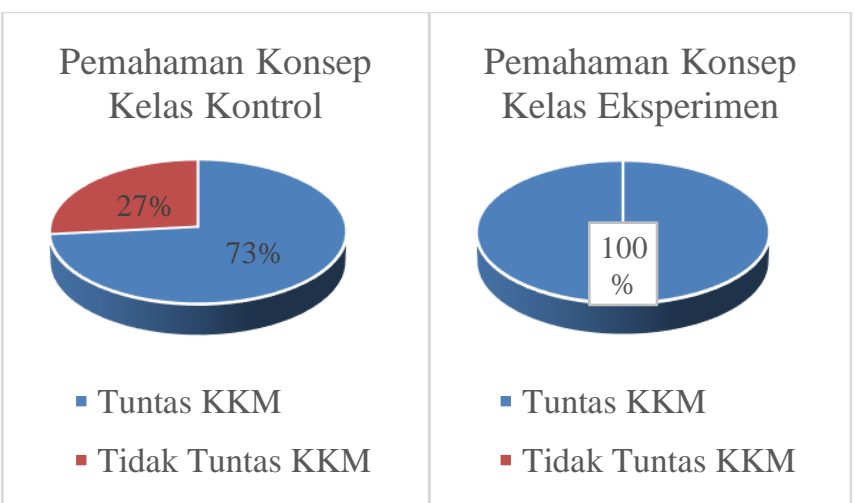

Gambar 2. Hasil Pemahaman Konsep Siswa Materi Struktur Bumi

Dari gambar 2 terlihat bahwa pada $100 \%$ siswa pada kelas yang diberikan perlakuan memiliki nilai postes memenuhi standar KKM, sedangkan pada kelas kontrol hanya $73 \%$ siswa yang memiliki nilai memenuhi standar. Hal ini menunjukkan bahwa pemahaman konsep materi struktur bumi pada siswa di kelas yang diberikan perlakuan lebih baik dibandingkan dengan siswa di kelas kontrol. 
Hasil uji normalitas pada nilai postes mendapatkan nilai seperti pada tabel berikut:

Tabel 9. Hasil Uji Normalitas

\begin{tabular}{ccc}
\hline \multirow{2}{*}{ Kelas } & \multicolumn{2}{c}{ Kolmogorov-Smirnov $^{\mathrm{a}}$} \\
\cline { 2 - 3 } & Statistik & Sig. \\
\hline Kontrol & 0,13 & 0,14 \\
Eksperimen & 0,13 & 0,16 \\
\hline
\end{tabular}

Berdasarkan tabel 9 di atas, diketahui nilai signifikansi yang diperoleh sebesar 0,14 pada kelas kontrol dan 0,16 pada kelas eksperimen. Nilai-nilai tersebut lebih dari 0,05 , maka dapat dikatakan data terdistribusi normal.
Selanjutnya dilakukan uji homogenitas pada nilai postes dengan hasil seperti pada tabel berikut:

Tabel 10. Hasil Uji Homogenitas

\begin{tabular}{cccc}
\hline Lavene's Test & $\mathrm{df}_{1}$ & $\mathrm{df}_{2}$ & Sig. \\
\hline 0,002 & 1 & 118 & 0,961 \\
\hline
\end{tabular}

Dari tabel 10 bisa dilihat nilai signifikansi yang didapatkan sebesar 0,961 . Karena nilai sig. 0,961 >0,05, maka dapat disimpulkan bahwa nilai postes pada kelas kontrol dan kelas eksperimen adalah sama atau homogen.
Setelah diketahui data terdistribusi normal dan homogen, dilaksanakan uji $\mathrm{t}$ nilai postes siswa untuk mengetahui perbedaan hasil pemahaman konsep materi struktur bumi antara kelas kontrol dan eksperimen.

Tabel 11. Hasil Uji t Nilai Postes

\begin{tabular}{ccc}
\hline & $\begin{array}{c}\text { Sig. Levene's Test for Equality } \\
\text { of Variances }\end{array}$ & $\begin{array}{c}\text { Sig. t-test for Equality of } \\
\text { Means }\end{array}$ \\
\hline Equal variances assumed & 0,02 & 0,00 \\
Equal variances not assumed & & 0,00 \\
\hline
\end{tabular}

Dari tabel 11 diatas, dapat dilihat nilai signifikansi yang didapatkan sebesar 0,00 . Nilai Sig. $000<0,05$ sehingga dapat disimpulkan bahwa terdapat perbedaan hasil pemahaman konsep materi struktur bumi yang berarti antara kelas kontrol dan kelas eksperimen. Berdasarkan nilai deskriptifnya terbukti kelas eksperimen mendapatkan rata-rata nilai postes yang lebih baik yakni 86,9.

\section{SIMPULAN}

Berdasarkan hasil pembahasan di atas, maka dapat disimpulkan bahwa produk media pembelajaran IPA emodul berbasis multiple intellegences materi struktur bumi menarik bagi siswa kelas VII SMP Negeri 1 Sugio. Siswa yang menggunakan media pembelajaran IPA emodul berbasis multiple intellegences memiliki pemahaman konsep yang lebih baik dibandingkan dengan siswa yang menggunakan bahan ajar konvensional.

\section{DAFTAR RUJUKAN}

Alice, Y. L., Lee. (2016). Teaching Media Literacy through Laptop Computers and Ipads. Media Education in The School 2.0: Global Media and China, $1-5$

Chatif, Munif. (2012). Sekolahnya Manusia: Sekolah Berbasis Multiple Intellegence di Indonesia. Bandung: kaifa.

Cranmer, G. A. (2017). One-Group PretestPosttest Design. In The SAGE Encyclopedia of Communication Research Merthods, 1126 
Gardner, H. (1983). Frames of Mind: The Theory of Multiple Intellegences. New York: Basic Books

Hasanudin, C. (2017). Media Pembelajaran: Kajian Teoritis dan Kemanfaatan. Yogyakarta: Deepublish Publisher.

Hasanudin, C. (2020). Pengembangan emodul apresiasi sastra berbasis media flipbook digital dengan aplikasi kvisoft. Dalam A. Rahmat \& Yuhelson (Eds.), Media Pembelajaran Transformatif (halaman 57-70). Gorontalo. Indonesia: Ideas Publishing.

Hasanudin, C., \& Fitrianingsih, A. (2020). Verbal linguistic intelligence of the first-year students of Indonesian education program: a case in reading subject. European Journal of Educational Research, 9(1), 117-128. Doi https://doi.org/10.12973/eujer.9.1.117.

Holme, T. A., Luxford, C. J, dan Brandiet, A. 2015. Defining Conceptual Understanding in General Chemistry. Journal of Chemical Education, 92(9), 1477-1483

Mahmudah, M., \& Erni, Y. (2018). Studi Validitas dan Reabilitas Multimedia Interaktif Science Edutainment Pada Topik Bumi Untuk Siswa SMP Kelas VII. Jurnal Penelitian Fisika dan Aplikasinya (JPFA), 8(1), 42-50

Meilinda, R., N.Y., \& Ari, W. Interactive Emodule of Constructivism Based On Genetic Material to Increase The Concept Mastery of Biology Teacher in Secondary School. Makalah disajikan dalam Proseding The Third International Seminar on Science Education: "Challenging Science Education in The Digital Era", Palembang, 17 Oktober 2009
Nworgu, L.N., \& Victoria, V.O. (2014). Effect of Guided Inquiry with Analogy Instructional Strategy on Students Acquisition of Science Process Skills. Journal of Education and Practice, 4(27), 35-40

Samiasih, Reny, S., \& Henry, P. (2017). Pengembangan E-Module Mata Pelajaran Ilmu Pengetahuan Alam Pokok Bahasan Interaksi Makhluk Hidup Dengan Lingkungannya. Edcomtech. 2(2), 119-124

Sugianto, D., Ade, G.A., S.E., \& Yuda, M. (2013). Modul Virtual: Multimedia Flipbook Dasar Teknik Digital. Innovation of Vocational Technologi Education (INVOTEC), 9(2), 101116

Sugiyono. (2012). Metode Penelitian Kuantitatif, Kualitatif, dan $R \& D$. Bandung: Alfabeta

Suherman, Yuyus. Pengembangan Media Pembelajaran. Makalah disajikan dalam Diklat Profesi Guru PLB Wilayah X Jawa Barat Bumi Makmur, Bandung, 2008 